\title{
Carving the story: Recovering histories of Sepik art in the Jolika Collection
}

Sculpture et intrigues : la redécouverte d'histoires sur l'art du Sepik de la collection Jolika

\section{Christina Hellmich}

\section{(2) OpenEdition}

\section{Journals}

Electronic version

URL: http://journals.openedition.org/jso/8570

DOI: $10.4000 /$ jso. 8570

ISSN: $1760-7256$

\section{Publisher}

Société des océanistes

\section{Printed version}

Date of publication: 15 July 2018

Number of pages: $97-105$

ISBN: 978-2-85430-135-9

ISSN: 0300-953x

\section{Electronic reference}

Christina Hellmich, « Carving the story: Recovering histories of Sepik art in the Jolika Collection », Journal de la Société des Océanistes [Online], 146 | 2018, Online since 15 July 2020, connection on 25 July 2020. URL : http://journals.openedition.org/jso/8570 ; DOI : https://doi.org/10.4000/jso.8570 


\title{
Carving the story: recovering histories of Sepik Art in the Jolika Collection
}

by

\author{
Christina HELLMICH*
}

\begin{abstract}
The Jolika collection at the de Young museum in San Francisco, the largest display of New Guinea art in a United States art museum, is distinguished by an important group of historic works from the Sepik River region. Case studies of selected pieces highlight key curatorial issues and opportunities including cultural patrimony claims and the benefits of scientific testing. Ongoing engagement and collaboration with contemporary artists from Papua New Guinea and scholars and scientists in the field enables the museum to gather interpretative data, field documentation and object stories. As a result, names and histories are reconnected to figures and Sepik perspectives about authenticity and artistry are added to the public's understanding of the works.
\end{abstract}

KeYwords: Jolika Collection, New Guinea art, de Young museum, contemporary artists, scientific testing, National Cultural Property (NCP) of PNG

In 2005, the new de Young museum in San Francisco opened with an inaugural installation of over 400 works from the island of New Guinea. This constituted the largest display in a United States art museum offering a new opportunity for the public to view New Guinea visual culture. At the time of the opening, a Papua New Guinea newspaper, The National, announced that "Papua New Guinea has a new footprint in America - a big one" in the form of a permanent gallery for the Jolika Collection at the de Young Museum and highlighted the

\section{RÉSUMÉ}

La collection Jolika du musée de Young à San Francisco - la plus grande d'objets d'art de Nouvelle-Guinée présentée par un musée américain -, se distingue par son nombre d'objets anciens de la vallée du Sepik. L'étude de certaines pièces met en lumière les points clés du travail des conservateurs dont ceux portant sur la revendication de biens culturels patrimoniaux ou la savoir acquis grâce à des tests scientifiques. Des rencontres continues, que se soit par la collaboration avec des artistes contemporains de Papouasie Nouvelle-Guinée, des universitaires et des chercheurs spécialisés, permettent au musée de réunir interprétations, documentation de terrain et histoires d'objet. Ainsi les figures peuvent être reliées à des noms et à des histoires et les questions touchant à l'authenticité et aux talents artistiques peuvent aider à la comprébension des cuvres par le public.

Mots-CLÉs : collection Jolika, musée de Young, art de PNG, artistes contemporains, analyse scientifique, propriété culturelle nationale (NCP), PNG

monetary value of the collection as well as its cultural importance (The National, 2005). With this exhibition, the Jolika Collection of New Guinea art moved from the private sphere of a collector's home to a public institution.

\section{The Jolika Collection at the de Young Museum}

The complexities and opportunities of curating a collection assembled privately in the twentieth

* Curator in Charge, Department of the arts of Africa, Oceania and the Americas and the Jolika Collection of New Guinea Art, de Young Museum, Fine Arts Museums of San Francisco, chellmich@famsf.org 
century and now part of a public art museum collection include issues concerning cultural patrimony and scientific testing. New research, interpretation and exhibition methodologies are expanding the role of art museums in shaping public understanding of Sepik visual culture both past and present. Through ongoing programs engaging contemporary artists from Papua New Guinea and scholars and scientists from around the globe, the museum aims to provide alternative interpretative perspectives and expand the time depth of object histories to enrich understanding of New Guinea art. Case studies reveal the detailed histories of selected pieces from the Sepik River region and their multivalent lives as objects. They show how oral histories and extant documentation can shape our understanding of museum collections. The de Young museum - as an archive - is a place where memory is activated but also where the contemporary meaning and significance of artworks for different constituencies is generated and welcomed.

The M. H. de Young Memorial Museum opened in San Francisco on March 23, 1895. Its small holdings of art from Oceania are charter collections of the museum. They were presented at the California Midwinter International Exhibition of 1894 and subsequently purchased for the museum by the City of San Francisco through the efforts of M. H. de Young founder of the San Francisco Chronicle newspaper. The strength of this early collection resides in small groups of objects, including several important woodcarvings from Maori meetinghouses and singular works such as a rare Micronesian navigation figure. There are no Sepik pieces from this period. These collections were augmented in the early $20^{\text {th }}$ century by San Franciscans who travelled to the Pacific. But the collection grew by donation without a master plan. So, the arrival of the Jolika Collection of New Guinea art assembled by Marcia and John Friede over many decades transformed the profile of Oceanic visual culture at the de Young. A gallery was dedicated to the collection when the new de Young opened in 2005. The original building was badly damaged in the 1989 Loma Prieta earthquake and Swiss architecture firm Herzog \& de Meuron designed a new museum to showcase the collections of American paintings, sculpture and decorative art from the 17 th through the 20th centuries; textile arts; contemporary art from around the globe and arts of Africa, the Americas and Oceania.

Two issues quickly emerged when the Jolika Collection moved from the Friedes' home to the de Young gallery for public display. The first related to a personal collateral loan against the collection. The Friedes received a loan of many millions against works in their collection including many pieces on loan and promised to the museum. The collection also figured in an inheritance dispute between John Friede and his brothers involving legal action. Second, six works at the museum, all from the Sepik region, were identified by present and former staff of the National Museum and Art Gallery in Port Moresby as National Cultural Property (NCP) of Papua New Guinea as per the Cultural Property (Preservation) Ordinance of 1965 of the Territorial Administration, officialised by the National Cultural Property (Preservation) Act of 1978. While the works were not exported by the Friedes, it was alleged that they were exported illegally before the Friedes purchased them from dealers or at auction.

In 2008, at the height of the inheritance dispute and the financial issues that threatened seizure of collection works, the Ambassador of Papua New Guinea, Evan Paki, appealed to the courts and the museum to make sure that the collection remained intact and available to the public. There was particular concern about the National Cultural Property pieces because some were included on the list of collateralized artworks. Paki stated that,

"Through the entire Jolika collection at the de Young, my nation has a rich storehouse of knowledge here in the United States. The New Guinea art pieces here are an integral part of our storied cultural history... while the people of New Guinea no longer possess them... we have come to appreciate the collection as an extension of our nation's cultural treasures..." (Paki, 2008)

In 2010, a Statement of Understanding and Collaboration concerning the six Sepik works identified as National Cultural Property was signed by John Friede; Honorary Consul General of Papua New Guinea Charles Cheathem; Elizabeth Cheathem, Honorary Vice Counsul of Papua New Guinea; Fine Arts Museums director John Buchanan; and Papua New Guinea MP Charles Abel, Minister for Tourism, Arts and Culture; agreeing that the works will be

"held in trust for the Papua New Guinea government at the de Young Museum." (Fine Arts Museums San Francisco, 2010)

To resolve the financial debt in accordance with the legal settlement, it was necessary to forfeit pieces and identify works for immediate and future sale by public auction. With the recent resolution of the financial and legal matters, the Fine Arts Museums now retains just over 330 Jolika Collection works. The rest of the collection was dispersed by the Friedes.

\section{"Yesindima" - Four Masandenai masks of the same name}

An extraordinary mask is one of the six works held in trust for the government of PNG. Its story highlights concerns about cultural patrimony. It 


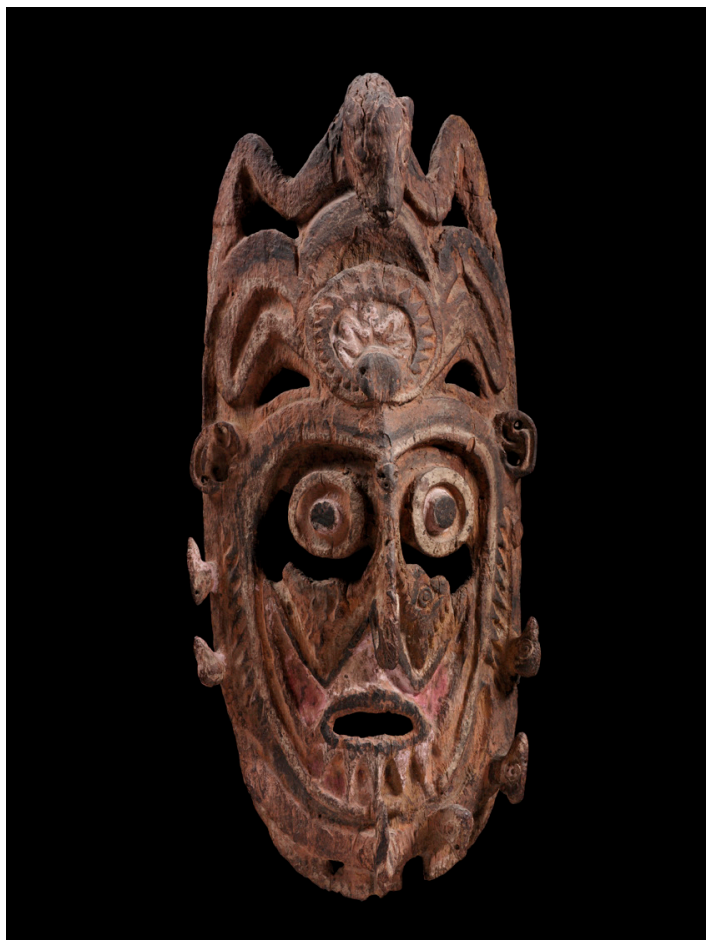

Рното 1. - Mask, "Yesindima”. Papua New Guinea, East Sepik Province, Masandamai (Masantoni, Masandenai) village on the Kenglame River (C) Fine Arts Museums San Francisco, L05.1.69 - Catalog no. 262)

also provides an exceptional view of Sepik artistic production, specifically, clan style and iconography over time and space and the relationship of these to views about authenticity in Sepik culture. Since the mask was originally viewed in 1967 and subsequently reported in 1973 , three additional masks, two recorded with the same name and all with similar iconography, have been documented (Gerrits, Email 15 July 2017 to Kaufmann; Papua New Guinea Public Museum and Art Gallery, 1973; Craig, 2005: 9; and Friede, 2007).

In 2006, Sebastine Haraha, an anthropologist at the Papua New Guinea National Museum and Art Gallery, visited the de Young museum at the museum's invitation to inspect the Jolika Collection pieces purported to be National Cultural Property. There is no database or publically available record of NCP works therefore complicating the ability of museums and collectors to verify the provenance of historic works from the Sepik that might have been registered as NCP decades ago. Haraha provided a scan of the NCP file record indicating that the original owner of this mask was a man named "Nokai, a member of the crocodile clan" in Masandenai village (Papua New Guinea Public Museum and Art Gallery, 1973). Barry Craig indicates that his full name is Nogwai (Nokai) Biso (Craig, 2005: 9). Fred Gerrits, a medical doctor at Angoram Hospital in the East Sepik District reported this data about the mask in 1973 having first seen and photographed it in January 1967 (Gerrits, 2017). Its name, "Yesindima" was recorded in 1982 (Papua New Guinea Public Museum and Art Gallery, 1973).

\section{The role of scientific testing}

Information about the mask has been derived from oral accounts gathered in the $20^{\text {th }}$ century by patrol officers and others connected to Australian colonial institutions. But, there is a much greater time depth for its creation and use. Barry Craig, former curator of Anthropology at the Papua New Guinea National Museum and Art Gallery in Port Moresby, states that the mask is

"the work of a master carver who lived well before Europeans arrived on the Sepik." (Craig, 2005: 8)

Fred Gerrits was told by the people in Masandanai that the mask had come from the Korowori area in the time of ancestors (Gerrits, 2017). Carbon dating of wood sampled from the back of the mask in two different locations $6 \mathrm{~cm}$ apart by Gregory Hodgins of the University of Arizona Accelerator Mass Spectrometry Laboratory suggests that the mask could be centuries old (Hodgins in Friede et al., 2005: 75-79). Hodgins' results indicate that the wood used to create the mask could date, in fact, from the $7^{\text {th }}-9^{\text {th }}$ century, the oldest wood among the 146 wood objects tested in the Jolika collection by Hodgins (Hodgins, 2010).

At this time we do not know when the mask was carved from the wood - the relationship between the fell date and the carving of the mask - and without knowing what tree rings (oldest or most recent) are present in the mask, the carbon dating might not provide the latest possible date of creation. Also, more research about the growth of wood species used for carving in the Sepik is needed to better interpret the carbon dating results. Finally, issues surrounding possible contaminants such as petroleum that can corrupt carbon dating results need to be considered, though unlikely in this case. As Gregory Hodgins has stated,

"radio carbon dating is so often necessary for understanding a piece but it is certainly not sufficient for understanding a piece... you have to use other historical, chemical, analytical or connoisseurship methods..." (Hodgins, 2010)

However, it is certain that carbon dating and other testing methods are redefining discussions concerning the time depth of Sepik artworks such as this mask.

In The Melanesian Way, Papua New Guinean politician and philosopher Bernard Narokobi 
(1937-2010), who was born in the East Sepik Province, states,

"Our history did not begin with our contact with the Western explorers. Our civilization did not start with the coming of the Christian missionaries." (Narokobi, 1983: 7)

\section{He asserts that,}

"Melanesians were... moving together long before Western contact. One needs only to reflect at the intricate trade links that extend across the island, the seas, the valleys, coastlines and the mountains to agree." (Narokobi, 1983: 10)

Scientific testing results, when considered along with archaeological, anthropological and linguistic data and oral accounts, can provide a fuller account of object histories.

\section{Iconography of the masks}

At the top of the Jolika mask, a flying fox sits with its head extended out over the front of the mask and wings outstretched. There are several concentric circles above the center of the forehead. The face is pierced and deeply carved with great detail accentuating ears with piercings, concentric eyes, a pierced nose and distinctive geometric shapes below the cheeks and mouth. Bird heads encircle the face on the outside edge of the mask. In an Oceanic Arts Society newsletter article about the Jolika mask, Barry Craig details a second mask with the same iconography carved by Mark Suwi of Masandenai in 1971 and owned by Samson Kavuli (Craig, 2005: 9). ${ }^{1}$ Kavuli traced the iconography back to Shotmeri, the first traditional Iatmul village on the Sepik and through another village before its arrival in Masandenai (Craig, 2005: 9). One difference between the masks is a dog, rather than a flying fox, at the top. Kavuli explained that the concentric circles found on both masks represent a lagoon with water lilies around it and that black cockatoo birds are at the bottom and white cockatoo birds at the sides (Craig, 2005: 9). While the Jolika mask might have been in use for several generations, its use did not preclude the creation of other contemporary masks based on the same iconography and given the same name.

A third mask named "Yesindima" - the name of the migratory ancestral crocodile for the clan was photographed by Craig in a community west of Ambunti in 1983. He recorded its carver, Nawamdambwi, and owner, Tolun'genaugwi (Craig, 2005: 9). While the overall form and composition of the mask is the same as the Joli- ka mask, a possum is represented at the top with birds and pigs along the outside edge. Craig's informants attributed it to the late $19^{\text {th }}$ century and said that sacrificial offerings of fowl or pigs were made to the mask during rituals to cure illness (Craig, 2005: 9). The fourth mask was purchased on Ebay in 2007 from an Australian dealer who listed the provenance as the collection of Gallery Tikowi, Cairns, Australia. The gallery was founded by Edward Boylan who began collecting in PNG in the 1970s through his association with the Paulian Missionary Society. Its deeply carved style and iconography is most similar to the Jolika mask including a flying fox at the top.

\section{“Original," copies, replacements and questions of authenticity}

Museums often rely on aesthetics and other formal qualities to identify what is considered authentic Sepik art. While copies and replacements are not valued as highly on the art market or in art scholarship, the Sepik artist and/or community that creates works might be much more concerned about efficacy and issues of cultural copyright. Ross Bowden's anthropological work in the Sepik has revealed how western notions of original works of art and copies are radically different from that of Kwoma society where he states that

"all works of art are thought to be replicas of earlier, pre-existing, objects." (Bowden, 1999: 335)

Bowden indicates that, Kwoma believe that a copy, provided it is well made, possesses all of the culturally and aesthetically significant features of an "original" or earlier work (Bowden, 1999: 335). He explains that, among the Kwoma

"'authenticity" is determined by two criteria: whether or not the object has been produced 'correctly' stylistically, and whether or not the individual (or group) who manufactured it had the right to do so." (Bowden, 1999: 335)

This discussion also pertains to Kayan masks as posited by Alexis Von Poser. In 2015, he indicated that it is usual for the Kayan to replace old wooden masks with new ones - "modernizing the image" - as long as they are recognized by the appropriate persons; the old mask can be given away without any problem (Poser, 2015). He stated that power could be transferred from the old mask to the new mask via a ceremony. Then, the "empty" mask can be dispersed (Poser, 2015). "Empty" is how it was explained to him in Kayan language. Poser states that, 


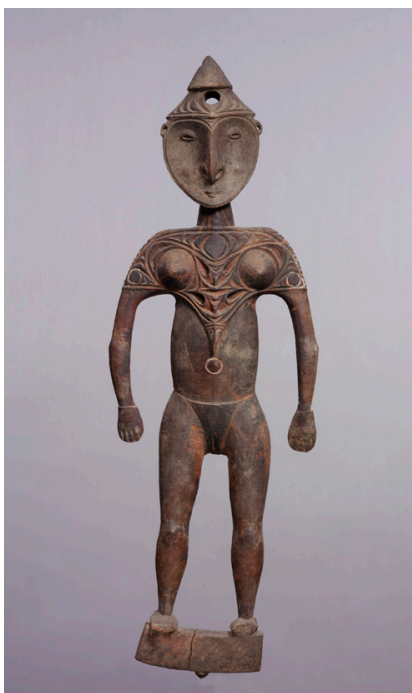

Рното 2. - Suspension hook, "Tangweiyabinjua". Papua New Guinea, Middle Sepik, Kandingai village, Nyaura clan (C) Fine Arts Museums San Francisco, L05.1.114 - Catalog no. 153)
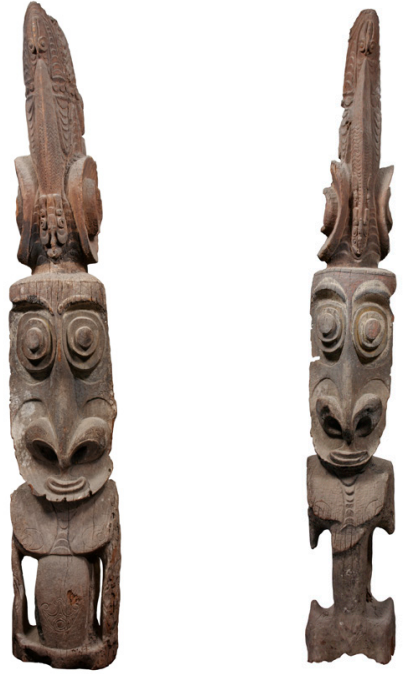

Рното 3. - House post figures, "Kwindiangget" and "Membengget". Papua New Guinea, East Sepik Province, middle Sepik River, Torembi village, $\mathrm{Ng}$ geitebma hamlet (CFine Arts Museums San Francisco, 2007.44.4 - Catalog no. 227 and 2007.44.5 - Catalog no. 228)

their collecting and exhibition methodologies. For museums, rarity and age are important classifications that justify value and collection. Copies are often considered derivative and fake. But, the importance of figures and masks in the Sepik is inextricably tied to their use and effectiveness. This is a difficult concept for viewers outside the Sepik with different belief systems and notions about the role of art in daily life. They might perceive aesthetic or material differences between multiple works with similar iconography and style without any understanding of their function or importance in their communities of origin. Sepik works were monetized as soon as outsiders arrived in the region. The example of Tangwei [Tangweiyabinjua] illustrates how one community

"Now the Kayan keep old masks in the men's house. But, previous generations gave them away, sold them or let them degrade." (Poser, 2015)

In a forthcoming book about the history of the Sepik region, former New Guinea Patrol Officer, Laurie Bragge, details his reports of artworks he encountered in the field including a female suspension hook in the Jolika Collection. His Situation Report from 1973 chronicles the name of the figure "Tangweiyabinjua" and its connection to a male figure "Mangisaun" now in the collection of the Papua New Guinea National Museum and Art Gallery (Bragge, 1973: 1 and Craig, 2010: 149-150). Replacement figures were carved for both at the time of their sale in the 1970s and documented by Bragge and Craig, respectively (Bragge, 1973: 4-5 and Craig, 2010: 150). Bragge's informants explained that,

"We have made a replacement for Tangwei [Tangweiyabinjua] and we have had a singing and given the names to the new Tangwei, and now we want to get rid of the old carving. We have all agreed to sell the old Tangwei, she has been here a long time and now we have replaced her." (Bragge, 1973: 4)

While the "Yesindima" mask in the Jolika collection is the most ancient, all four can be considered authentic. The art market and most museums would privilege the oldest mask considering it to be the original. However, it is possible that it is a replacement for an even older no longer extant mask. Historically, art museums have not incorporated indigenous concepts of authenticity into approached the sale of a very important carving by making a replacement that was imbued with the necessary powers - through "singing" and naming - to serve the community in the same way as the older figure. It was the newly carved figure that rose to importance.

\section{"Kwindiangget" and "Membengget" - two ancestor posts from Nggeitebma hamlet, Torembi village documented by field research}

The 2005 publication highlighting the Jolika collection (Friede et al., 2005) and its public exhibition offered collectors, scholars and curators across the globe, new access to the works previously held at the Friedes' home beyond public view. With their contributions to the inaugural publication, scholars in the field added to what was known about the works in the collection - the majority purchased by the Friedes from dealers or at auction. This research began a process to further reconnect pieces to their pasts. Collaborative research with other museums is also ongoing as Jolika works have ties to pieces and collections held by other institutions. Some were field collected and information can be obtained from field reports and often the anthropologists, scientists and dealers themselves through correspondence, meetings and visits to the de Young. Sometimes, as previous examples have shown, it is possible to learn more about their provenience - the exact location where works originated - and their former owners. Recovering the names of works is an 
exciting result that allows the public to appreciate New Guinea art in a new way - directly associated with its origin stories, clan and community and to better understand the formal aspects of its style as another example might show.

Three large-scale figurative post carvings representing great primordial clan ancestors survive from a men's ceremonial house in Torembi village destroyed by fire. Two of these figures made their way to the de Young and the third is now in the collection of the National Gallery of Australia in Canberra (National Gallery of Australia, NGA 1969.230.181). Another male figure from a neighbouring village in the same area and formerly part of a house post is now in the collection of the Museum der Kulturen in Basel and was included in the 2015 exhibition, Sepik. Arts de Papouasie Nouvelle-Guinée (Museum der Kulturen, inv. Vb 17702) (Peltier, 2015: 185).

Douglas Newton, former curator of the department of the arts of Africa, Oceania and the Americas at the Metropolitan Museum of Art, gave John Friede information about the Jolika carvings that was included in the inaugural exhibition catalogue (Friede, John, John Bigelow Taylor, and Dianne Dubler, 2005: 118). After their installation at the de Young, Virginia-Lee Webb, then research curator and senior research scholar at The Metropolitan Museum of Art, in the Department of the Arts of Africa, Oceania, and Americas, contacted the museum about color field photographs taken by English anthropologist J. Anthony Forge in 1960 showing the posts in situ. His notes include the names of all three posts: "Kwindiangget," elder brother, Nya'vi moiety; "Membengget," younger brother, Nyàvi moiety and "Mogulapan," Nyamei moiety (The J. Anthony Forge Archive, Metropolitan Museum of Art, New York, accession numbers PSC 2008. 14, 19, and 20).

Research and correspondence with other scholars continued for over a year. These photographs proved particularly important for the Canberra post. Crispin Howarth, Curator of Pacific Arts at the National Gallery, was able to determine that Brother Hubert Umlauf, associated with the Societas Verbi Divini or Missionaries of the Divine Word (svD) in Wewak collected the figure and the museum purchased it in 1969 from Father Heinemann (Heinemans) of svD (Howarth, 2008). Anthropologist Christian Kaufmann went back to his field notes and confirmed that all three posts came from an earlier ceremonial house. He wrote,

"I saw the posts in 1966 as did Forge and Bühler in 1959.” (Kaufmann, June 7, 2008)

"Indeed, I saw the three post figures at Torembi village, and wrote down their names." (Kaufmann, June 9, 2008)
Markus Schindlbeck conducted ethnographic research in Nangusap (Sawos) village and explains that the names of the posts are associated with clan moieties but might refer to the name of the post or the name of a figure or main figure carved on the post,

“... certain men's houses belong to either the 'nyame' (mother) moiety or the 'nyaui' (sun) moiety. This is common to all Middle Sepik communities... it can be assumed that the two posts with the names Kwindianngget and Membengget are closely related and I suspect even that it is a pair of names belonging to the 'nyaui' moiety. At the moment I cannot explain 'kwindia' but the other particle 'membe' is quite common like in the widespread name 'Membenwoli' for a women. Different and clearly not from the same moiety is the name 'Mogulapan'." (Schindlbeck, 2017)

The names of heroic clan ancestors represented in the figurative carvings and their associated moieties also relate to the structure of the ceremonial house, as described by Markus Schindlbeck, Meinhard Schuster, Eike Haberland and others (Schindlbeck, 1985 and 2017). As a result of these multiple field reports and photographs, we now have more detailed information, including the given names, of these important and related monumental carved posts.

\section{“Wispange:" - a trumpet from Palimbei village documented by contemporary artists}

The de Young collaborates with contemporary artists from New Guinea to interpret works for visitors. Their voices help us balance our interpretative focus. Western art museums of the last four centuries and the collectors who supported them, often did not gather information from the creators of Oceanic art they acquired. So, most of the histories related to these works in art museum collections focus on the life of works after they have left the community that created them and used them. The focus is on the collectors and the information they gathered and subsequent research. Provenance - the history of their trade, transfer and sale - is the determining factor in their value rather than indigenous perspectives about their value, quality and style. James Clifford, Linda Tuhiwai Smith and many others have called out this cultural exclusion in hopes that other stories can be told.

An important trumpet in the collection, named "Wispange" from Palimbei village, was documented as NCP and described by Dirk Smidt in 1971 (Papua New Guinea Public Museum and Art Gallery, 1971). This information, including a description of its formal qualities, formed the basis of its documentation until it was exhibited at the de Young in 2005. A companion trumpet, 
named "Kasapange," is in the National Museum of Papua New Guinea (Craig, 2010: 196-197). In 1981, Barry Craig was told that the trumpets

"date back to the beginning of things when the Sepik basin was a huge swampy lagoon called Mevenbit. But one day the Sepik broke through at Kopar and the huge lagoon drained away into the sea." (Craig, 2010: 196)

Craig indicates that the area was inhabited by two groups of people who founded the first settlements on the Sepik (Craig, 2010: 196). While c-14 dating of the Jolika trumpet does not corroborate such ancient origins, it does suggest that the trumpet could be hundreds of years old and reflect a dynamic social landscape.

In 2006, carver Teddy Balangu from Palimbei village visited the de Young and related that this trumpet is from a subclan of Palembei clan located in Dabu (Balangu, 2006). Dabu is the shortened version of Indabu, a village which split from Palimbei and moved upriver. He explained that,

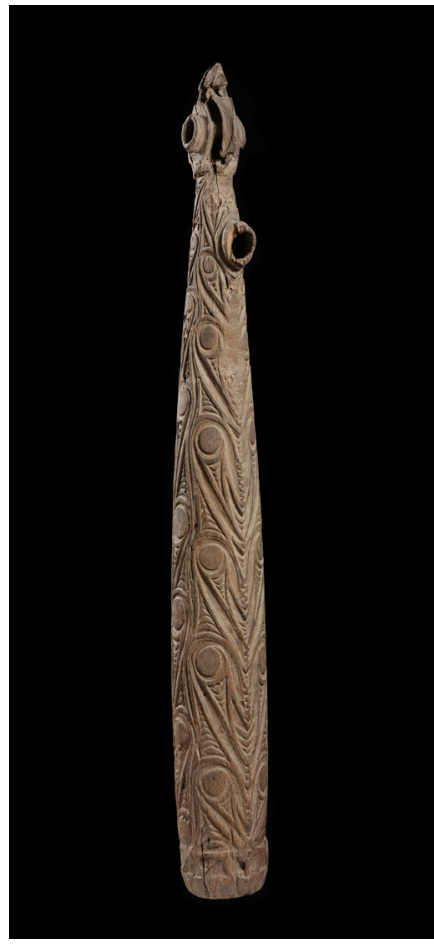

Рното 4. - Trumpet, "Wispange" (Papua New Guinea, East Sepik Province, middle Sepik River, Indabu village (C) Fine Arts Museums San Francisco, L05.1.159 - Catalog no. 184) success as they approached home. The people in their village would then begin singing and dancing to welcome them back. A pair of long and short trumpets like these are still used today during the young men's initiation. They're sounded when the boys emerge from the spirit house as men. For a lesser occasion, the trumpets can be used separately. To play this instrument, the entire mouth is placed over the main hole, then the lips are tensed and a strong breath produces the sound." (Yambon, 2009)

Artists activate works in the de Young museum through their interpretation providing new information about historic carvings. Decoded iconography and cultural connections engages viewers seeing the works through a contemporary lens. Cataloguing work with contemporary artists has limitations. Artists comment on the works they recognize in the collection and feel comfortable talking about. Their engagement might be restricted to pieces from their clan or village and might include one or just a few pieces in the collection. Also, cultural knowledge can vary greatly between different individuals and

"each clan had a trumpet and each clan had a war canoe. Battles were fought for land and fishing areas and happened between the canoes on the open water. One man was positioned in front to shield from spears and arrows. If he died, the second man in line became the defender. All other men in the canoe were shooting arrows and spears. Upon return to the village, a man would blow the trumpet for each head taken in battle." (Balangu, 2006)

Balangu also revealed the iconography illuminating new information to share with museum visitors. He explained that the top of the trumpet is a human face. The hole between the ears was for a hanging rope and the design motifs covering the surface of the trumpet are a series of interconnected whirlpools and waves of the Sepik River (Balangu, 2006).

In 2009, Iatmul master carver Claytus Yambon, of Korogo village, also provided documentation during a visit to the de Young, stating that,

"carved into this ceremonial trumpet is the design common to all Iatmul clans: it represents waves and water. The animal at the top denotes the particular clan this belongs to. On a head hunting expedition, two of these would be carried in a canoe: a long one and a shorter one. Returning from a successful outing, the party would blow these in alternation to announce their over time within a community. But, visiting the collection in San Francisco, rather than working from documentation and photographs remotely, allows artists and/or community members access to their cultural patrimony for their own purposes and the museum unmediated information and data to better understand the works.

\section{The Cassowary Woman - a carving and a story}

When Teddy Balangu and Claytus Yambon spent time in the gallery at the de Young both commented on a remarkable figurative flute ornament depicting a woman in the middle of transforming into a bird - a beaked head sitting atop her human form. Yambon stated that,

\footnotetext{
"This sculpture of a cassowary lady is probably Sawos (from Yamok, Torembi, and surrounding villages). On this figure, you can see a small human head behind the bird's beak. This refers to the transformation in the following story, which is owned by the cassowary clan of the Iatmul." (Yambon, 2009)
}

A version of the story is also told by Arnold J. Ambu, a carver from Kaminibit who specializes 


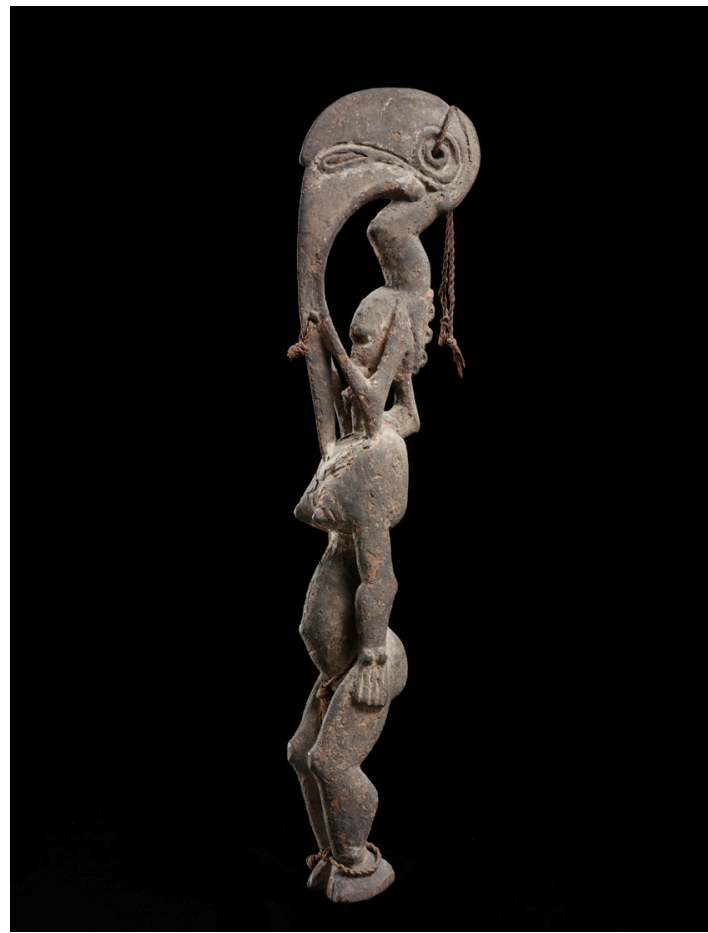

Рното 5. - Ornament for sacred flute (Papua New Guinea, East Sepik Province, middle Sepik River, Sawos (C) Fine Arts Museums San Francisco, L05.1.42 - Catalog no. 236)

in carving contemporary images of this figure for the art market (Ambu, 2015 and Yambon, 2009).

"Long ago, there lived a man in a village who had no wife. His parents had died when he was a small boy and he was raised by his grandparents. He had never been loved by a woman and he was very lonely.

One morning he got up early, took his bows and arrows, and went into the bush. He hunted all day, but he didn't find any pigs, wallabies, or cassowaries. He felt very tired, so he sat beside a pool to rest before going home. It was late in the afternoon when he heard the footsteps of cassowaries from behind the bushes. He hid to watch them as they approached. Suddenly, he saw them come straight to the pool. They took off their skins as if they were costumes; underneath were women. They jumped into the water to wash. After washing, they changed back into their costumes and as cassowaries took off to the jungle. The man sadly left his hiding place, feeling very disappointed, as he really wanted to marry one of those ladies.

Early next morning, he returned to the same place to hide and wait for the cassowaries to come and wash. Soon they arrived and once more took off their skins. The lonely man crawled out of hiding and hid the skin of the youngest one. After washing, the women jumped back into their skins and took off to the jungle, leaving the youngest behind. She searched everywhere but her cassowary skin was not to be found. She began to cry for her skin. Meanwhile, the man left his hiding place and came out to see her. He asked, 'Why are you crying?' She replied, 'Oh good man, I'm crying for my skin. Somebody stole it, and I can no longer follow my friends.' The man laughed inside because he loved the cassowary woman. He said, 'Don't cry and worry about your skin. It is getting late and soon it will be dark: you won't find it. Tomorrow, I will help you find it and then you can return to your friends.

The two went to the man's village with the cassowary skin hidden in his bilum (string bag). Later they were married, raised a family and lived happily ever after. That is the story of how the cassowary tribe came to my village. It is the story of my ancestors, because my father is from the cassowary tribe and so am I.

In another version of the story, the man hides the woman's cassowary costume on the roof of his house so that she can't find it. Years later, the couple's children discover it while playing on the roof, and they inform her. She retrieves the costume, transforms, and takes the children away to live in the jungle. The man never sees his family again.” (Ambu, 2015)

The Jolika collection includes two "cassowary woman" flute ornaments and when questioned about multiple representations of the same image, Yambon indicated it is not necessary to have an existing sculpture to guide a carver in making another similar representation as they carve from the story (Yambon, 2009). Stories - conveyed from clan to clan, village to village, and generation to generation - shape the stylistic canon and enliven the carvings with power.

Many Sepik works in museums are simply identified as "Sepik" with perhaps a culture identifier such as "Iatmul" and assigned a date of " $19^{\text {th }}$ century" or " $20^{\text {th }}$ century." Recovering the histories and reconnecting names and stories to works in the Jolika Collection engenders new understandings of Sepik visual culture for museum audiences and scholars alike. To know the name of a figurative carving or mask is to know its identity - a simple but very transformative moment for a museum object. Its place and importance in the collection and the larger corpus of Sepik art is changed forever. These curatorial efforts involving many people and institutions working collaboratively illustrate that multidisciplinary collections research and engagement with communities where works originated can yield rich documentation for museum interpretation and allow contemporary artists and indigenous scholars unique experiences to study historic works held outside New Guinea.

\section{REFERENCES}

Aмbu Arnold, 2015 (October 20). (Cassowary story). Email communication from Elaine Monds to Christina Hellmich.

Balangu Teddy, 2006 (October 13). Personal Communication with Christina Hellmich.

Bowden Ross, 1999. What Is Wrong with an Art Forgery?: An Anthropological Perspective, The 
Journal of Aesthetics and Art Criticism 57 (3), pp. 333-343 (www.jstor.org/stable/432198).

Bragge Laurie W., 1973. Situation Report No. 1, Ambunti Patrol No. 1/1973-74, October 17, 1973, pp. 1-5.

Craig Barry, 2005. Notes on a mask in the John Friede collection, OAS Newsletter 10 (4), pp. 8-9.

Craig Barry, Mark Busse, Soroi Marepo Eoe, David Becker, A. L. Crawford and National Museum and Art Gallery (Papua New Guinea), 2010. Living Spirits with Fixed Abodes: The Masterpieces Exhibition: Papua New Guinea National Museum and Art Gallery, Honolulu, University of Hawai'i Press.

Friede John, John Bigelow TAYlor and Dianne Dubler, 2005. New Guinea art: Masterpieces from the Jolika Collection of Marcia and John Friede, San Francisco, Fine Arts Museums of San Francisco in association with 5 Continents Editions, Milan.

Friede John, 2007 (April 19). Email communication to Christina Hellmich.

Fine Arts Museums San Francisco, 2010 (June 9). "Statement of Understanding and Collaboration".

Gerrits Fred, 2017 (July 15), Email communication to Christian Kaufmann.

Howarth Crispin, 2008 (March 3). Email correspondence with Christina Hellmich.

Hodgins Gregory, 2010 (February 11). Radiocarbon Dating of Museum Objects (accessed 06/20/2017: https://deyoung. famsf.org/radiocarbon-dating-museum-objects-dr-greg-hodgins).

KaUfmann Christian, 2008 (June 7). Email correspondence with Christina Hellmich.
-, 2008 (June 9). Email correspondence with Christina Hellmich.

—, 2012. Object file notes, AOA department, FAMSF.

—, 2016. Object file notes, AOA department, FAMSF.

Narokobi Bernard, 1983. The Melanesian Way, Boroko, Papua New Guinea, Institute of Papua New Guinea Studies.

The National, 2005 (October 27) "Valued at US\$100 million..." Letter to the Editor [no author listed] (accessed on website 10/27/2005).

Papua New Guinea Public Museum and Art Gallery, 1971. National Cultural Property File \#17.

—, 1973. National Cultural Property File \#56.

PAKI Evan, 2008 (October 6). Letter from Ambassador Evan J. Paki, Embassy of Papua New Guinea, to John E. Buchanan, Jr., Director, Fine Arts Museums of San Francisco.

Peltier Philippe. 2015. Sepik. Arts de Papouasie Nouvelle-Guinée, Paris, Gallimard.

Poser Alexis von, 2015. Kayan in the 2010s. A Change in Spiritual Representations at the North Coast of New Guinea. Symposium presentation: The materiality of Sepik societies 2015: New visions, old problems, musée du quai Branly, Paris, October 27-28, 2015.

SchindLbECK Markus, 1985. Männerhaus und weibliche Giebelfigur am Mittelsepik, PapuaNeuguinea, Baessler-Archiv 33, pp. 363-411.

-, 2017 (August 15). Email correspondence with Christina Hellmich.

Yambon Claytus, 2009. Personal Communication with Christina Hellmich, October 9, 2009 transcribed by Dan Lepsoe, October 18, 2009. 
